\title{
Tribute to the Memory of Dr. Nishida
}

\author{
$\operatorname{AUTHOR}(\mathrm{S}):$ \\ Sakamaki, Tetsuya
}

CITATION:

Sakamaki, Tetsuya. Tribute to the Memory of Dr. Nishida. Pan Africa News 2011, 18(special issue): 11-11

ISSUE DATE:

2011-09

URL:

http://hdl.handle.net/2433/147277

RIGHT:

Copyright (C) Pan Africa News. 
walking, play, and other behaviors. He always commented on the observed behavior and often let out a hearty chuckle, which was also recorded on the videotapes.

At first, he seems to have collected visual data to examine the regional differences in chimpanzee behavior. Later, he shifted his interests to the play of young chimpanzees and novel behaviors of Mahale chimpanzees, and the video camera proved to be an effective tool for this research. His accumulated visual data, and the data that Dr. T. Matsusaka and I obtained were collected and presented as an audio-visual ethogram of Mahale chimpanzees at his retirement party in 2004. I asked him to open the video ethogram, and he agreed. Subsequently, videos of chimpanzees in other areas were added with the cooperation of Dr. Crickette Sanz, Dr. David Morgan and Dr. G. Ohashi, and "Chimpanzee Behavior in the Wild: An Audio-Visual Encyclopedia" was published in 2010.

His chuckle in the DVD that comes with this book reminds me that he really enjoyed his fieldwork in Mahale and loved chimpanzees.

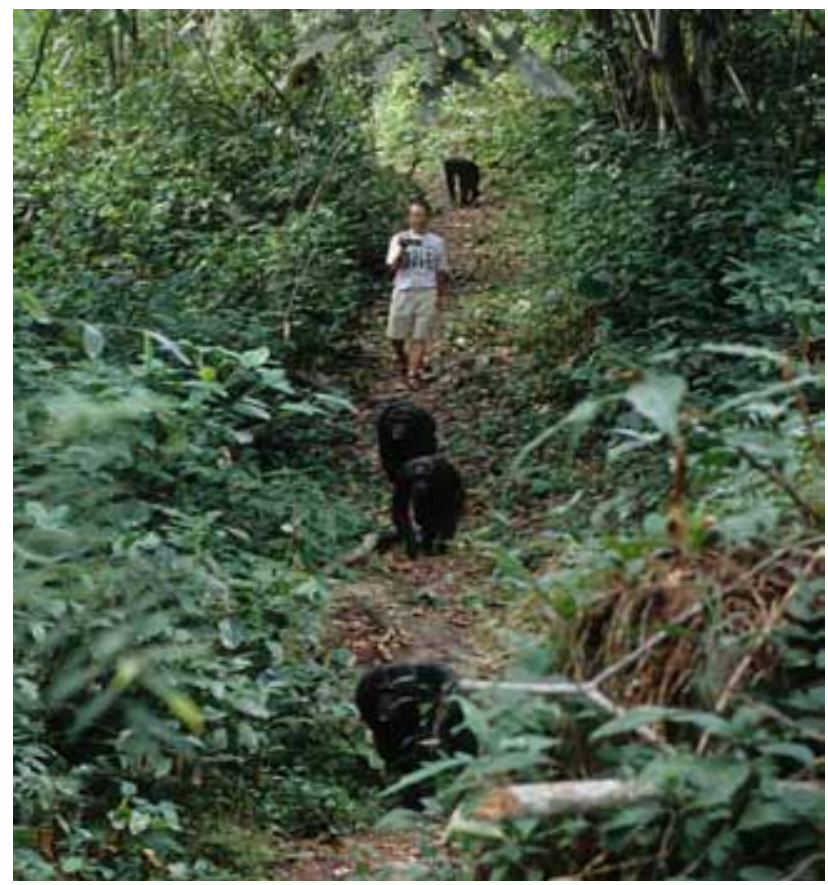

Dr. Nishida taking video of the chimpanzees of Mahale in 1999.

\section{Tribute to the Memory of Dr. Nishida}

\section{Tetsuya Sakamaki \\ Kyoto University, Japan}

"Don't be stingy when food is available in the field." This is one of the secrets that I learned from Dr. Nishida when I stayed with him in Mahale. I don't remember if he told it to me in words or if he conveyed it with his actions. In either case, the importance of this lesson has increased as I have expanded my work to new or remote areas. I now know that special and delicious foods can be found in the field and that searching for and finding them brings tremendous joy, which leads to additional discoveries.

\section{Memories of Nishida-san}

\author{
Takahisa Matsusaka \\ Kansai University, Japan
}

I deeply regret the passing of Nishida-san. About 5 years ago, I was greatly shocked when he told me that he had cancer. However, he continued his research; he kept returning to Mahale, publishing papers, and writing books. I was always overwhelmed by his endless enthusiasm and energy as a researcher on the front lines. Such zest for work gave me hope that somehow he might be able to overcome his illness.

I first met Nishida-san as an undergraduate student. His lecture "Anthropology" was one of the most interesting that I ever took at Kyoto University. Even though his passion sometimes "derailed" his talks, they remained exciting and fruitful. I was simply fascinated by his enthusiasm, and I did not hesitate to join his laboratory. I am deeply indebted to Nishida-san for whatever I have achieved. He allowed me to join his chimpanzee research project at Mahale, supervised my thesis, and helped me have a job at the Japan Monkey Centre. I was greatly honored to work with him on several studies on Mahale chimpanzees, such as those on cultural behaviors as well as the audio-visual encyclopedia (ethogram).

I have fond memories of the time I spent with Nishida-san at Mahale. I walked with him in the forest several times; I followed him while he video-recorded the chimpanzees, and I learned about them from his video narrations as well as how to observe them. It was really nice time to share our observations at the Kansyana base camp. When I described my observations to him, he always listened intently and gave other examples from his own experience or encouraged me to write about them. I also have unforgettable memories of special dinners with him, such as sashimi and ryukyu of "nkuhe" from Lake Tanganyika and sukiyaki. He never forgot to chill beer by wrapping the bottles with wet towels (We didn't have a refrigerator at Kansyana). He once showed me how to cut and trim fish for sashimi, so that I could even enjoy sushi at Mahale. Having dinner with Nishida-san was always fun, since he made us laugh with jokes. I miss his smiling face.

At his funeral, I put a flower at his feet in respect for how long he had walked in the field and to represent all of his honorable contributions. I imagined that Nishida-san would walk again in the forest of Mahale, talking with the old Tongwe people, and meeting Ntologi, Kamemanfu, Chausiku, Masudi, and all the other chimpanzees whose legends Nishida-san recorded.

\section{Tribute}

$$
\begin{aligned}
& \text { Eiji Inoue } \\
& \text { Kyoto University, Japan }
\end{aligned}
$$

As an undergraduate student at Kyoto University, I took an anthropology course by Prof. Nishida. I remembered that he showed us videos of chimpanzees several times during his lectures and he talked enthusiastically about them. I talked with him for the first time when I asked his advice on my graduation work in his laboratory. I was surprised that he recognized me. He said to me, "You 